On the Influence of Trades, Professions, and Occupations in the United States, in the Production of Disease

By Dr. Benjamin W. McCready, 1837. (Publications of the Institute of the History of Medicine, the Johns Hopkins University, Fourth Series: Bibliotheca Medica Americana, Vol. 4.) Pp. viit 129. (Baltimor3, Md.: Johns Hopkins University, 1943.) 1.75 dollars.

$\mathrm{T}$ HE study of industrial diseases is a subject which, for obvious reasons, received little attention from medical men until comparatively recent times. Bernardino Ramazzini's "De morbis artificum diatribum" of 1700 was the first comprehensive work on occupational diseases, and the second was that of Thackrah of Leeds published in 1831. This latter work and the growth of industrialization in the United States of America influenced the Medical Society of the State of New York to propose for a prize essay in 1835 the subject of "The influences of trades, professions and occupations in the United States in the production of disease". The winner of the prize was a twenty-three year old physician, Benjamin W. MeCready, and his essay was first published in 1837. This book contains the original essay with a critical historical introduction by Genevieve Miller.

The essay consists of four sections, discussing thirty-one employments. The first deals with outdoor workers in agriculture, on canals and railways, labourers and seamen; the second describes the workers in the textile industry; the third deals with artisans and tradesmen; and the fourth with the professional men.

MeCready saw that in many cases the industrial hazards of his day were eaused as much by basic habits and environmental conditions as by any immediate dangers in the occupations. The remedies he proposed were simple-proper housing and ventilation, personal cleanliness, shorter working hours and more exercise.

The editor and publishers are to be congratulated on their reproduction of this important historical document.

\section{Civilization and Disease}

By Prof. Henry E. Sigerist. Pp. xii $+255+29$ plates. (Ithaca, N.Y.: Cornell University Press; London: Oxford University Press, 1943.) 22s. 6d. net.

ISEASE has played a great part in the evolution of eivilization. Dr. Sigerist develops the theme and demonstrates the interrelationship in its many aspects in the course of human history. He begins by describing the influence of external factors of living conditions, clothing, lighting and nutrition on the genesis of disease, and then passes on to particulars. Economic and industrial changes and their effects on the character of disease are illustrated by reference to the works of Ramazzini, McCready and Thackrah. The position of the sick in society has greatly changed from the earliest days, when they were ostracized as in the case of lepers or horribly confined if mentally ill. In the complex modern society, many sick persons can usefully be employed in selected occupations.

The law appears in the establishment of quarantines, in the licensing and regularization of medical practice, and in publie health and industrial organization.

The course of history has at all times been subject to influence by disease in epidemic form, and reference is made to the effects of plague, typhus and melaria on the results of battle and on distribution of population.

Towards the end, Dr. Sigerist becomes discursive and sketches over the relationship between religion, metaphysies, science, the arts and disease.

The subject-matter of this book was first used as a series of lectures, and this is apparent in the style. The wideness of scope and paucity of detail make this very readable book more suitable for the sociologist and lay reader than for the student of the history of medicine. The volume is beautifully produced, and has excellent and interesting illustrations.

\section{Thermionic Valve Circuits}

By Dr. Emrys Williams. Second edition. Pp. viii +207. (London: Sir Isaac Pitman and Sons, Ltd., 1944.) 12s. 6d. net.

7 HE first edition of this book was reviewed in I Nature of July 18, 1942. According to the author's preface: "The appearance of a second edition of this book has been hastened by the extensive consumption of the first edition by the enemy Luftwaffe". The opportunity has been taken to increase the size by some 15 per cent, by a general expansion of the existing chapters. New material has been added dealing with such subjects as frequency modulation, gas-filled valves, time bases, the Kipp relay, the transitron and the cathode follower; but the author has rightly resisted any inclination to go too far in meeting the general eriticism of incompleteness. The book remains a very good survey of all the main types of valve circuits, presented in such a way that the student may be in a position to understand, or even foresee, further developments.

\section{Pacific Ocean Handbook}

By Eliot G. Mears. Pp. viii +192. (Stanford University, Calif.: James Ladd Delkin, 1944.) 1 dollar. DROF. ELIOT G. MEARS, professor of geography in Stanford University, set himself a formidable task in compressing into less than two hundred small pages a survey of the current scientific knowledge of the Pacific Ocean and its adjacent lands. There are chapters on the structure of the basin, its islands, on the physical aspects of the waters including drifts and currents, and on every aspect of the climate and particularly the storms. Other chapters deal with navigation, magnetism and tides. All sections are amply illustrated with maps. When such a degree of condensation is demanded, minor slips are unavoidable; but on the whole the little volume is most informative on the scientific side and includes results of much recent work. There are also statistical appendixes and a folding map.

Textbook of Histology for Medical Students By Dr. Evelyn E. Hewer. Third edition. Pp. xii + 364. (London : William Heinemann (Medical Bookss), Ltd., 1944.) 17s. $6 d$. net.

THE essentials of normal histology are simply stated in this short text-book. The illustrations are excellent, and the photomicrographs by $\mathbf{E}$. V. Willmott deserve special mention. As a laboratory reference book for medical students engaged on practical histology or preparing for examinations, this could not be bettered. 